\title{
Air Environment Pollution and Management Measures at Bulk Terminals
}

\author{
Lei $\mathrm{Sun}^{1}$, Shoushui $\mathrm{Yu}^{2}$, and $\mathrm{Yan}_{\mathrm{Ji}^{2}}$ \\ ${ }^{1}$ Tianjin Research Institute for Water Transport Engineering, Key Laboratory of Environmental Protection Technology on Water \\ Transport, Ministry of Transport, Tianjin, China \\ ${ }^{2}$ Qingdao port (Group) Co., Ltd
}

\begin{abstract}
In order to comprehensively evaluate the air pollution control status of bulk terminals, the atmospheric environment control measures and effects of Qingdao port Qiangang company in Shandong Province were studied. By means of field survey, monitoring and data analysis, the present situation of atmospheric environment of the research object was analyzed quantitatively, and compared with the national standards. The research results show that the atmospheric environment and main characteristic pollutants at the boundary of the terminal operation area meet the standard requirements under the premise of using spray, cover, windbreak and other management measures during the monitoring period.
\end{abstract}

\section{Introduction}

At present, the earth inhabited by human beings is facing serious challenges. In the situation of global warming and frequent natural disasters, it is already the trend and urgent to change the mode of economic development, build livable cities, build a happy harbor and achieve green development. Especially, ports are not only a barometer of the global economy and important driving force for world economic growth, but also one of the world's major energy consumption and pollution sources.

On September 19, 2019, the Central Committee of the Communist Party of China and the State Council issued the Outline for the Construction of A Transportation Power, which calls for the creation of a green and efficient modern logistics system. On November 13, 2019, the Ministry of Transport joint multiple ministries issued the Guidance on the Construction of World-Class Ports, which calls for the construction of a safe convenient, smart green, economical efficient, supportive and powerful, world-class port with a focus on the hub port. Efforts should be made to strengthen pollution prevention and control, promote the prevention and control of pollution in ports and ships, optimize the pollution control modes, improve the system of environmental protection standards, strengthen dust and dust suppression measures for bulk operations, strictly implement the joint regulatory system for the transfer of hazardous waste and ship water contaminants,speed up the electronic management of documents and multi-sectoral sharing.

The problem of dry bulk pier pollution is relatively prominent in business classification.

Qingdao Port as the world's largest ore import port, China's important coal loading and unloading port, has a strong representative, Therefore, this paper selects a bulk pier in Qingdao Port in the daily operation of the atmospheric environmental impact of analysis

\section{Project Overview}

\section{1 Project Basics}

The total investment of the project is RMB 4.65 billion. The total area of the port area is about 3 square kilometers, the yard area is 1.81 million $\mathrm{m}^{2}, 16$ million tons of storage capacity. It now manages the use of 9 deep-water berths in 4 piers with an annual design throughput capacity of 69 million tons. The pier currently has 3 bulk berths of 200,000 tons and 2 bulk berths of 150,000 tons, the total length of the shore line is $2480 \mathrm{~m}$, and the total area of the production auxiliary building is $18295 \mathrm{~m}^{2}$, which includes integrated buildings, office buildings, mobile machinery depots, railway buildings and so on. The company's main business scope includes: bulk storage, loading and unloading, handling and site, machining and other business.

\subsection{Operating conditions}

Business scope includes: coal and a small amount of ore loading and unloading, storage. The piles of stocks are coal, iron ore and bauxite. The number of jobs for the project in 2016 is shown in the table below. 
Table 1. Company's 2016 Cargo Throughput List (t)

\begin{tabular}{|c|c|c|}
\hline \multirow{2}{*}{$\begin{array}{c}\text { Foreign trade } \\
\text { import }\end{array}$} & Minerals & $\mathbf{2 0 1 6}$ \\
\cline { 2 - 3 } & Iron ore & 53359139 \\
\cline { 2 - 3 } & Coal & 5049391 \\
\hline \multirow{2}{*}{ Exports } & Coal & 1050180 \\
\cline { 2 - 3 } & Iron ore & 18504380 \\
\hline \multirow{2}{*}{$\begin{array}{c}\text { Domestic trade } \\
\text { imports }\end{array}$} & Coal & 2373376 \\
\cline { 2 - 3 } & Iron ore & 8743615 \\
\hline \multirow{2}{*}{$\begin{array}{c}\text { Domestic trade } \\
\text { exports }\end{array}$} & Other ming & 0 \\
\cline { 2 - 3 } & Iron ore & 9152303 \\
\hline
\end{tabular}

\subsection{Climate conditions}

The project located in Qingdao's West Coast New Area, which located in the northern temperate monsoon region, is a temperate monsoon climate. Because of the direct regulation of the marine environment and the influence of the southeast monsoon and currents and water groups from the ocean, the region has significant oceanic climate characteristics. The air is humid, and the rainfall is abundant. The temperature is moderate, and the four seasons are clear.

Spring temperature rebounds slowly, 1 month later than inland, summer is wet and rainy, but no heat, autumn is high and cool, precipitation is less, evaporation is strong, winter is windy and low temperature, longer duration. According to more than 100 years of meteorological data since 1898 , the average annual temperature in urban areas is 12.2 degrees Celsius, extreme high temperature is 37.4 degrees Celsius (July 27, 1997), and extreme low temperature is -16.4 degrees Celsius (January 10, 1931).August is the hottest month of the year, with an average temperature of 25.1degrees Celsius; and January is the coldest, with an average temperature of -1.2 degrees Celsius. The number of days with a maximum daily temperature above 30 degrees Celsius averages 11.4 days per year; and a daily minimum temperature of less than -5 degrees Celsius, with an average of 22 days a year.

The annual average of precipitation is $775.6 \mathrm{~mm}$, and the rainfall in spring, summer, autumn and winter is $14 \%$, $57 \%, 22 \%$ and $7 \%$ of the annual rainfall, respectively. Annual precipitation is up to $1272.7 \mathrm{~mm}$ (1911), at least $308.2 \mathrm{~mm}(1981)$, and the annual variation is $62 \%$. The average annual snowfall is only 10 days. The average annual pressure is 1008.6 millibars. The average annual wind speed is $5.3 \mathrm{~m} / \mathrm{s}$, South-east wind as the dominant wind. Average annual relative humidity is $73 \%$, the highest in July, at $89 \%$, and the lowest in December, at $68 \%$.

Qingdao West Coast New Area belongs to the East Asian monsoon zone, the normal wind direction is southeast, the next normal wind direction is north and north-northwest, the strong wind direction and the sub-normal wind direction are basically the same. The average annual wind speed is $5.3 \mathrm{~m} / \mathrm{s}$, with a maximum wind speed of $38 \mathrm{~m} / \mathrm{s}$.

\subsection{Loading and unloading machinery}

Table 2. List of Major Handling Equipment (Consolidated)

\begin{tabular}{|c|c|c|c|}
\hline Serial number & Device name & Model/Load & $\begin{array}{l}\text { Number } \\
\text { (Taiwan) }\end{array}$ \\
\hline 1 & Loader & САТ980H & 22 \\
\hline 2 & Loader & CAT980GII & 8 \\
\hline 3 & Loader & САТ966H & 6 \\
\hline 4 & Loader & $\begin{array}{c}\text { Komatsu } \\
\text { WA380 }\end{array}$ & 4 \\
\hline 5 & Loader & $\begin{array}{l}\text { Komatsu } \\
\text { WA470 }\end{array}$ & 13 \\
\hline 6 & Excavator & $\begin{array}{c}\text { Komatsu } \\
\text { PC360 }\end{array}$ & 6 \\
\hline 7 & Excavator & $\begin{array}{c}\text { Komatsu } \\
\text { PC300 }\end{array}$ & 9 \\
\hline 8 & Excavator & $\begin{array}{c}\text { Komatsu } \\
\text { PC240 }\end{array}$ & 6 \\
\hline 9 & Excavator & $\begin{array}{c}\text { Komatsu } \\
\text { PC220 }\end{array}$ & 2 \\
\hline 10 & Excavator & $\begin{array}{c}\text { Hyundai } \\
\text { R60-7 }\end{array}$ & 1 \\
\hline 11 & Dumper & $\begin{array}{c}\text { Mine } \\
\text { Overlord }\end{array}$ & 30 \\
\hline 12 & Dumper & Howe & 7 \\
\hline 13 & $\begin{array}{c}\text { Railway } \\
\text { locomotives }\end{array}$ & DF4DD & 1 \\
\hline 14 & $\begin{array}{c}\text { Railway } \\
\text { locomotives }\end{array}$ & DF12 & 6 \\
\hline 15 & Forklift & HT30Ds & 4 \\
\hline 16 & Forklift & CPCD30 & 1 \\
\hline 17 & Forklift & CPCD60-W2 & 3 \\
\hline 18 & Forklift & CPCD100 & 1 \\
\hline 19 & Forklift & CPCD50 & 1 \\
\hline
\end{tabular}

\subsection{Process}

Qiangang Branch specializes in ore, coal two major cargo types loading and unloading, of which coal loading and unloading process is shown in the figures below. 
(1) Coal loading and unloading process:

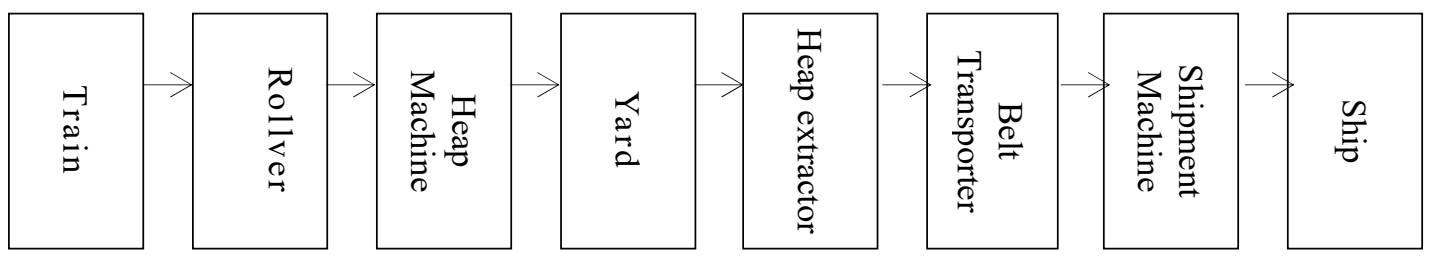

Figure.1. Coal loading and unloading process flow chart

(2) Ore loading and unloading process:

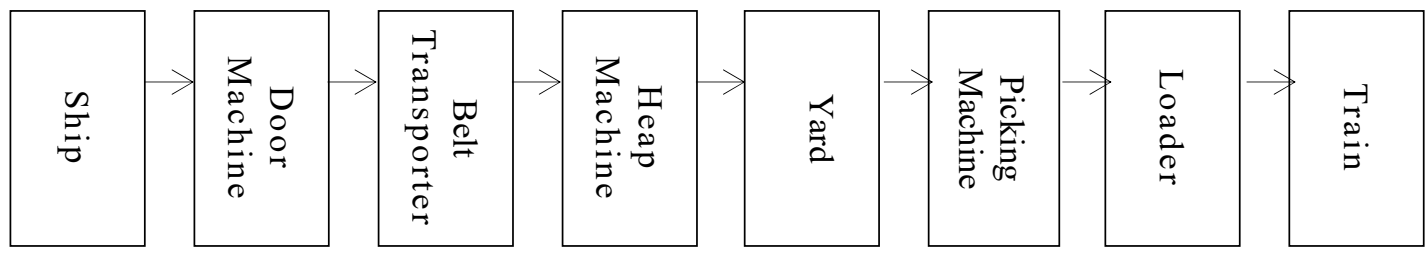

Figure.2. Ore loading and unloading process flow chart

(3) Small port pond loading and unloading process:

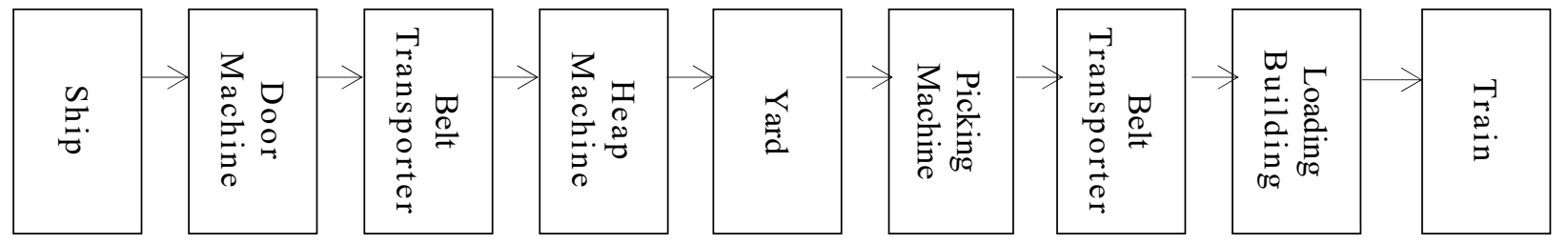

Figure.3. Small Port Pond Loading and Unloading Process Flow Chart

\section{Environmental air background analysis}

\subsection{Status of environmental air quality}

(1) Monitoring projects and monitoring methods Monitoring projects include $\mathrm{PM}_{10} 、 \mathrm{PM}_{2.5} 、 \mathrm{SO}_{2} 、 \mathrm{NO}_{2}$ 、 $\mathrm{CO} 、 \mathrm{O}_{3}$.

Continuous sampling for 7 days, monitoring methods adopted the Technical guidelines For environmental impact assessment-Atmospheric Environment(HJ2.2-2018) 、 Air and exhaust gas monitoring and analysis methods and Ambient air quality standardands(GB3095-2012) so on the technical specifications

(2) Survey Time and Survey Station

The statistics of Yellow Island Monitoring Station of the atmospheric environment can be found in Table 4-1 from April 20, 2019 to April 24, April 28 and April 29, 2019.

Table 3. Statistics on the monitoring of pollutants in the ambient air of monitoring stations in Yellow Island

\begin{tabular}{|c|c|c|}
\hline $\begin{array}{c}\text { Monitoring } \\
\text { projects }\end{array}$ & $\begin{array}{c}\text { Daily mean } \\
\left(\mathbf{g} / \mathbf{m}^{\mathbf{3}}\right)\end{array}$ & $\begin{array}{c}\text { Secondary environmental } \\
\left.\text { quality standards } \mathbf{( s g} / \mathbf{m}^{\mathbf{3}}\right)\end{array}$ \\
\hline $\mathrm{SO}_{2}$ & $1-6$ & 150 \\
\hline $\mathrm{NO}_{2}$ & $5-11$ & 80 \\
\hline
\end{tabular}

\begin{tabular}{|c|c|c|}
\hline $\mathrm{PM}_{10}$ & $6-34$ & 150 \\
\hline $\mathrm{PM}_{2.5}$ & $2-22$ & 75 \\
\hline $\mathrm{CO}$ & $\begin{array}{c}0.562-0.767 \mathrm{~m} \\
\mathrm{~g} / \mathrm{m}^{3}\end{array}$ & $4 \mathrm{mg} / \mathrm{m}^{3}$ \\
\hline $\mathrm{O}_{3}$ & $63-86$ & $\begin{array}{c}160 \text { (maximum } 8 \text { hours a } \\
\text { verage day) }\end{array}$ \\
\hline
\end{tabular}

According to the relevant regulations of the land environmental protection department, the atmospheric environmental quality of the Yellow Island area implements the requirements of the secondary standards in the Ambient air quality standards(GB3095-2012). As can be seen from the monitoring data above, the ambient air background value of the Yellow Island area where the project is located is good, $\mathrm{PM}_{10}, \mathrm{PM}_{2.5}, \mathrm{SO}_{2}$, $\mathrm{NO}_{2}, \mathrm{CO}, \mathrm{O}_{3}$ and other indicators can meet the requirements of the secondary environmental quality standards in the Ambient air quality standards (GB3095-2012).

\subsection{Analysis of the production and pollution link}

Combined with on-site investigation and analysis of existing projects, the main atmospheric pollutant generation nodes during the current project operation period include:

(1) Coal and ore unloading vessels, belt machine transport, storage and loading process of dust, the main pollution process as detailed in the figure below; 
(2) Secondary dust edgy dust on roads and piers under the effect of wind;

(3) During the loading and unloading process of the pier, the atmospheric pollutants emitted by the diesel loading and unloading machinery are mainly nitrogen oxides;

(4) Canteen oil smoke;

(5) Welding soot in the equipment maintenance area;

\section{3 Analysis of the project's atmospheric environment compliance}

(1) Evaluation criteria

The environmental factors for this evaluation are: $\mathrm{PM}_{10}, \mathrm{PM}_{2.5}, \mathrm{SO}_{2}, \mathrm{NO}_{2}$, the evaluation method is evaluated using the Ambient air quality standards (GB3095-2012) and the relevant standards for the revised order of supporting environmental monitoring standards.

(2) Evaluation results and analysis

According to the evaluation mode, the environmental quality index of each pollutant is calculated, and the results are shown in the table below.

Table 4. Evaluation results of the current status of the average daily concentration of conventional pollutants

\begin{tabular}{|c|c|c|c|}
\hline $\begin{array}{c}\text { Monito } \\
\text { ring p } \\
\text { rojects }\end{array}$ & $\begin{array}{c}\text { Daily mean } \\
\left(\mathbf{g} / \mathbf{m}^{\mathbf{3}}\right)\end{array}$ & $\begin{array}{c}\text { Secondary environ } \\
\text { mental quality stan } \\
\text { dards } \mathbf{( s g / \mathbf { m } ^ { 3 } )}\end{array}$ & $\begin{array}{c}\text { Excess r } \\
\text { ate } \mathbf{( \% )}\end{array}$ \\
\hline $\mathrm{SO}_{2}$ & $1-6$ & 150 & 0 \\
\hline $\mathrm{NO}_{2}$ & $5-11$ & 80 & 0 \\
\hline $\mathrm{PM}_{10}$ & $6-34$ & 150 & 0 \\
\hline $\mathrm{PM}_{2.5}$ & $2-22$ & 75 & 0 \\
\hline
\end{tabular}

The evaluation results show that the daily average concentrations of $\mathrm{SO}_{2}, \mathrm{NO}_{2}, \mathrm{PM}_{10}$ and $\mathrm{PM}_{2.5}$ in the evaluation area meet the requirements of the secondary standards in the Ambient air quality standards (GB3095-2012).

\subsection{Air pollution sources monitor and compliance analysis of the project at the plant boundary}

For the port dust pollution is the main source of air pollution, and the coal ore pier in the loading and unloading operations and open storage of wind erosion process TSP and $\mathrm{PM}_{10}$ is the main component of dust, so on May 21, 2019, the port area TSP contribution was investigated and monitored, monitoring the normal production operation during the monitoring period, the meteorological conditions and monitoring results during the monitoring period are shown in the table below.
Table 5.Weather conditions during monitoring

\begin{tabular}{|c|c|c|c|c|c|c|c|}
\hline $\begin{array}{l}\text { Detec } \\
\text { tion } \\
\text { point } \\
\text { s }\end{array}$ & $\begin{array}{l}\text { Dete } \\
\text { ction } \\
\text { Time }\end{array}$ & $\begin{array}{l}\text { Aver } \\
\text { age } \\
\text { wind } \\
\text { dire } \\
\text { ction }\end{array}$ & $\begin{array}{l}\text { Aver } \\
\text { age } \\
\text { wind } \\
\text { spee } \\
\text { d (m } \\
/ \text { s) }\end{array}$ & $\begin{array}{l}\text { Atmo } \\
\text { spheri } \\
\text { c Pre } \\
\text { ssure } \\
\text { (kPa) }\end{array}$ & $\begin{array}{l}\text { Weat } \\
\text { her c } \\
\text { ondit } \\
\text { ions }\end{array}$ & $\begin{array}{l}\mathbf{T} \\
\mathbf{S} \\
\mathbf{P}\end{array}$ & $\begin{array}{l}P \\
M \\
10\end{array}$ \\
\hline \multirow[t]{2}{*}{$\begin{array}{c}\text { Gate } \\
6\end{array}$} & $\begin{array}{c}0: 00 \\
-0 \text { : } \\
00 \mathrm{t} \\
\text { he } \mathrm{n} \\
\text { ext d } \\
\text { ay }\end{array}$ & $\begin{array}{l}\text { North } \\
\text { west }\end{array}$ & 3 & 101 & Clear & $\begin{array}{c}15 \\
3\end{array}$ & / \\
\hline & $\begin{array}{c}0: 00 \\
\sim 20: \\
00\end{array}$ & $\begin{array}{l}\text { North } \\
\text { west }\end{array}$ & 3 & 101 & Clear & / & 99 \\
\hline \multirow[t]{2}{*}{$\begin{array}{l}\text { Offic } \\
\text { e Bui } \\
\text { lding }\end{array}$} & $\begin{array}{l}0: 00 \\
-0 \text { : } \\
00 \quad t \\
\text { he } n \\
\text { ext d } \\
\text { ay }\end{array}$ & $\begin{array}{l}\text { North } \\
\text { west }\end{array}$ & 2.9 & 101 & Clear & $\begin{array}{c}14 \\
9\end{array}$ & / \\
\hline & $\begin{array}{c}0: 00 \\
\sim 20: \\
00\end{array}$ & $\begin{array}{l}\text { North } \\
\text { west }\end{array}$ & 2.9 & 101 & Clear & / & 94 \\
\hline \multirow[t]{2}{*}{$\begin{array}{c}\text { Pump } \\
\text { No. } \\
2\end{array}$} & $\begin{array}{l}0: 00 \\
-0 \text { : } \\
00 \quad t \\
\text { he n } \\
\text { ext d } \\
\text { ay }\end{array}$ & $\begin{array}{l}\text { North } \\
\text { west }\end{array}$ & 3.1 & 101 & Clear & $\begin{array}{c}15 \\
7\end{array}$ & / \\
\hline & $\begin{array}{c}0: 00 \\
\sim 20: \\
00\end{array}$ & $\begin{array}{l}\text { North } \\
\text { west }\end{array}$ & 3.1 & 101 & Clear & / & 81 \\
\hline \multirow[t]{2}{*}{$\begin{array}{c}200,0 \\
00 \text { pi } \\
\text { ers }\end{array}$} & $\begin{array}{l}0: 00 \\
-0 \text { : } \\
00 \mathrm{t} \\
\text { he } \mathrm{n} \\
\text { ext d } \\
\text { ay }\end{array}$ & $\begin{array}{l}\text { North } \\
\text { west }\end{array}$ & 3 & 101 & Clear & $\begin{array}{c}14 \\
5\end{array}$ & / \\
\hline & $\begin{array}{c}0: 00 \\
\sim 20: \\
00\end{array}$ & $\begin{array}{l}\text { North } \\
\text { west }\end{array}$ & 3 & 101 & Clear & l & 76 \\
\hline \multirow{2}{*}{$\begin{array}{l}100 \\
\text { millio } \\
\mathrm{n} \text { ton } \\
\mathrm{s} \text { of } \\
\text { sculpt } \\
\text { ure }\end{array}$} & $\begin{array}{l}0: 00 \\
-0 \text { : } \\
00 \mathrm{t} \\
\text { he } \mathrm{n} \\
\text { ext d } \\
\text { ay }\end{array}$ & $\begin{array}{c}\text { North } \\
\text { west }\end{array}$ & 3.1 & 101 & Clear & $\begin{array}{c}14 \\
7\end{array}$ & / \\
\hline & $\begin{array}{c}0: 00 \\
\sim 20: \\
00\end{array}$ & $\begin{array}{l}\text { North } \\
\text { west }\end{array}$ & 3.1 & 101 & Clear & / & 88 \\
\hline \multirow{2}{*}{$\begin{array}{c}\text { Flow } \\
\text { Flee } \\
\text { t Co } \\
\text { mpou } \\
\text { nd }\end{array}$} & $\begin{array}{l}0: 00 \\
-0 \text { : } \\
00 \mathrm{t} \\
\text { he } \mathrm{n} \\
\text { ext d } \\
\text { ay }\end{array}$ & $\begin{array}{l}\text { North } \\
\text { west }\end{array}$ & 2.9 & 101 & Clear & $\begin{array}{c}14 \\
1\end{array}$ & / \\
\hline & $\begin{array}{c}0: 00 \\
\sim 20: \\
00\end{array}$ & $\begin{array}{l}\text { North } \\
\text { west }\end{array}$ & 2.9 & 101 & Clear & / & 86 \\
\hline \multicolumn{6}{|c|}{ Reference standard limits } & $\begin{array}{c}30 \\
0\end{array}$ & $\begin{array}{c}15 \\
0 \\
\end{array}$ \\
\hline
\end{tabular}

According to the monitoring results, the maximum concentration of TSP at the point of detection is $0.157 \mathrm{mg} / \mathrm{m}^{3}$, The maximum concentration of $\mathrm{PM}_{10}$ is 
$0.099 \mathrm{mg} / \mathrm{m}^{3}$, which meets the requirements of the concentration limit of non-organized emission

\section{Key environmental management measures during the operation period}

During the operation of the project, atmospheric pollutants mainly come from the following aspects: Dust generated by the work of the yard, welding soot generated by machining, exhaust gas fromVOCs loading and unloading machinery and transport vehicles, and canteen smoke. In view of the above pollution nodes, enterprises in the field of atmospheric environmental protection has carried out the following management measures: yard

(1) Dust control measures from the operation of the

(1) In loading and unloading ship operations in the grapple equipped with a spray device, and the grapple closed, to minimize the material grasping process of dust diffusion.

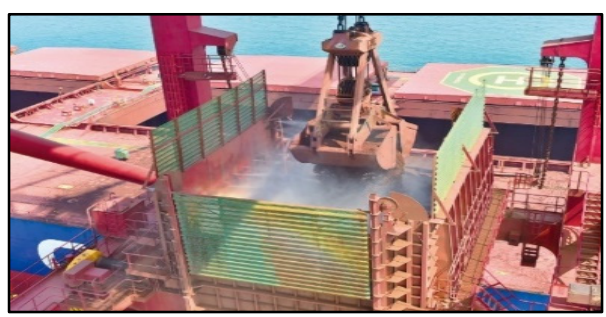

(2) In the belt machine material transport process to close the belt machine, reduce the belt machine in the transport of materials in the wind erosion effect.

(3) Equipped with a fixed fog gun, 1 mobile fog gun. Daily spray and dust removal in the work area of the yard; equipped with 577 fixed water guns, automatic sprinkler guns 117, and in the process, the reproduced building added sprinklers 612 groups, 24 hours non-stop on the work site and the operation process of sprinkler dust.

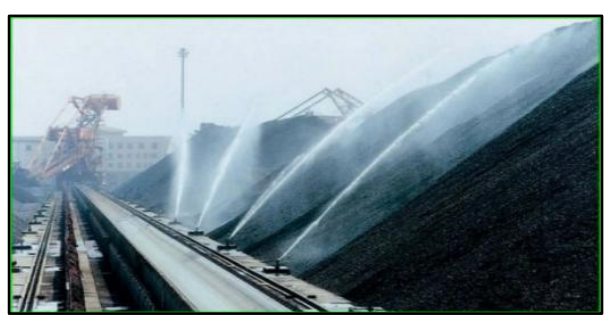

(4) Wind-proof net: around the boundary of the plant built a length of up to 2500 meters wind net, so that the wind-proof network around the factory area is basically closed, the height of 18 meters, the material for polymer composite dust-suppressing plate. monitoring of particulate matter in Integrated emi ss i on standards for air Pollutants (GB16297-1996).

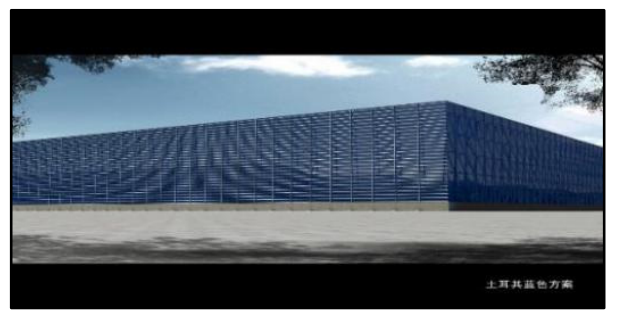

(5) The coal and ore cargo piles in the yard area were covered.

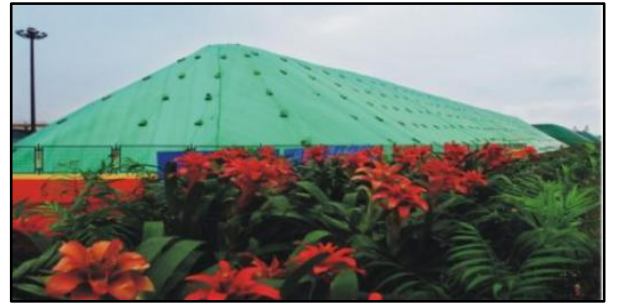

(6) Environmental monitoring early warning system: the company in the yard with 3 real-time atmospheric monitoring points, with the company's competent departments leader's phone connectivity, real-time grasp of the plant air quality.

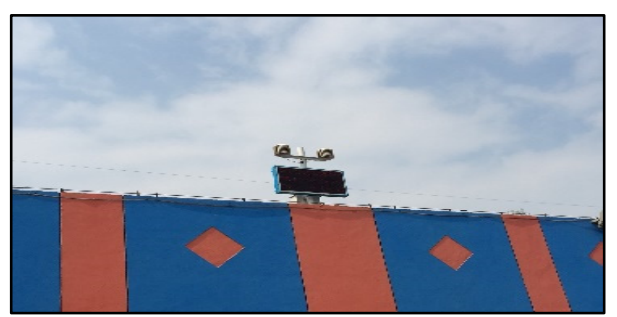

(7) Regular cleaning and spray on the factory road to reduce the road dust rate.

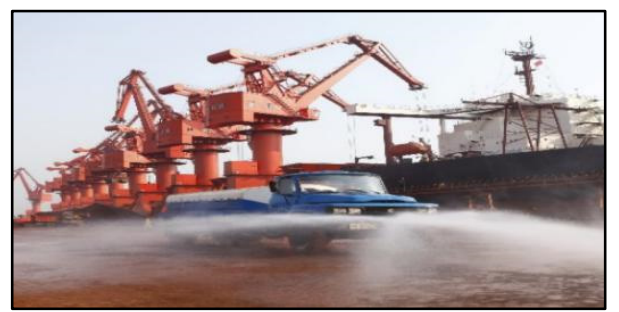

(2) Exhaust emissions from loading and unloading machinery and transport vehicles

The pollutants in the exhaust gas are mainly $\mathrm{NO}_{2}$ and so on, which are less emitted and are mobile, and their impact on the atmospheric environment is not obvious. However, in order to ensure the quality of ambient air, the construction unit has taken the following measures:

(1) Shop environmentally friendly and efficient loading and unloading machinery and transport vehicles that emit less pollutants. 
(2) Strengthen the maintenance and repair of machinery and vehicles to keep them running normally and reduce pollutant emissions

(3) Use qualified fuel oil to add fuel aids to the fuel oil of diesel-fueled machinery to allow it to burn fully and reduce emissions of pollutants from exhaust gases

(4) Divert the traffic in the field and reduce the idle travel time for machinery and vehicles in order to reduce the emission of pollutants.

\section{Conclusions}

(1) During the monitoring period, the environmental air background quality of Yellow Island area in the area where the pier is located was good, and there was no serious pollution.

(2) $\mathrm{PM}_{10}, \mathrm{PM}_{2.5}, \mathrm{SO}_{2}, \mathrm{NO}_{2}$ in the pier operations area during monitoring meet the requirements of the secondary standards in the Ambient air quality Standards(GB3095-2012).

(3) Emissions of major atmospheric characteristic pollutants (TSP and $\mathrm{PM}_{10}$ ) in the pier operations area during monitoring meet the requirements of the monitoring concentration limits for particulate matter non-organizational emissions in the Integrated emission standards for air Pollutants(GB16297-1996)

(4) Air pollution prevention and control such as spray, cover, wind screen closure and other management measures reasonable and effective, and in line with the current national environmental protection policies and regulations.

\section{Acknowledgment}

Fund Project, National Key R\&D Program of China 2016YFE02044800.

\section{References}

1. Technical guidelines for environmental impact assessment -Atmospheric Environment(HJ2.2-2018)

2. Air and exhaust gas monitoring and analysis methods

3. Ambient air quality standards(GB3095-2012)

4. Integrated emission standards for air pollutants(GB16297-1996)

5. Specifications on environmental protection design for port and waterway engineering(JTS149-2018) 